American Journal of Agricultural and Biological Sciences 7 (2): 217-223, 2012

ISSN 1557-4989

(C) 2012 Science Publications

\title{
Capability of Streptomyces spp. in Controlling Bacterial Leaf Blight Disease in Rice Plants
}

\author{
${ }^{1,2}$ Ratih Dewi Hastuti, ${ }^{1}$ Yulin Lestari, \\ ${ }^{2}$ Rasti Saraswati, ${ }^{1}$ Antonius Suwanto and ${ }^{3}$ Chaerani \\ ${ }^{1}$ Department of Biology, Faculty of Mathematics and Natural Sciences, \\ Bogor Agricultural University, Darmaga Campus, Bogor 16680, Indonesia \\ ${ }^{2}$ Indonesian Soil Research Institute, J1. Ir. H. Juanda 98, Bogor 16123, Indonesia \\ ${ }^{3}$ Indonesian Center for Agriculture Biotechnology and Genetic Resources \\ Research and Development, Jl. Tentara Pelajar 3A Bogor 16111, Indonesia
}

\begin{abstract}
Problem statement: Bacterial Leaf Blight (BLB) caused by Xanthomonas oryzae pv. oryzae $(X \circ o)$ is the most damaging disease in lowland rice growing areas in Indonesia. Streptomyces spp. have been known as a producer of antimicrobial compounds that can be used as biocontrol agents. This study examined the ability of three promising indigenous Streptomyces isolates which were previously selected from in vitro agar media and greenhouse test to suppress natural infection of Xoo during dry and wet season trials in 2009/2010 at the Muara Experimental Research Station, Bogor West Java, Indonesia. Approach: Streptomyces isolates (PS4-16, LBR-02 and LSW-05) were applied through seed coating in a peat-based carrier followed by seedling soaking, spray treatment, or combination of both methods, either singly or in combination of two or three isolates. The number of Streptomyces population in the peat carrier at the time of inoculation was above $10^{7} \mathrm{cell} \mathrm{g}^{-1}$. The efficacy of Streptomyces was compared to that chemical spray using NORDOX 56 WP (a.i., zinc oxide $56 \%)$ and non-treatment. Treated and untreated seeds were grown in plots $\left(5 \times 5 \mathrm{~m}^{2}\right)$ and set in a randomized complete block design with four replications. Results: In the dry season experiment, application of Streptomyces spp. reduced BLB severity when compared to that of untreated plots, although did not reduce BLB incidence. PS4-16, applied singly through seed coating followed by seedling soaking, reduced the Area Under Disease Progress Curve (AUDPC) at 70 Days After Planting (DAP) to 1458 , which was equally effective to the chemical spray (AUDPC value 1434) and simultaneously promoted plant height and gave the highest rice yield. In the wet season trial PS4-16 and LBR-02, applied singly or in dual combination through seed coating followed by seedling soaking, suppressed BLB severity, PS4-16 was confirmed as the most effective isolate by reducing the AUDPC to 1923, which was not significantly different to the AUDPC value obtained from chemical spray treatment (1934). Conclusion/Recommendations: All Streptomyces isolates had a tendency to increase plant and yield compared to the chemically-sprayed and non-treated plots. For successful biological control of rice BLB, further development of a better formulation for long-term storage with an effective population density of Streptomyces and an assessment of its field efficacy in multi-location trials are needed.
\end{abstract}

Key words: Bacterial Leaf Blight (BLB), Xanthomonas oryzae pv. oryzae, Streptomyces spp., rice plant

\section{INTRODUCTION}

Bacterial Leaf Blight (BLB) caused by Xanthomonas oryzae pv. oryzae (Xoo) is the most important disease of lowland rice growing areas in Indonesia. The disease affects rice production quantity of decreasing harvest and weight of 1000 grains and qualitatively by impairing grain filling and increasing grain vulnerability during milling process. Crop losses due to Xoo infection have been reported since $10-95 \%$.

BLB disease is difficult to control effectively. Rice varieties with race-specific resistance have been the most important method to control BLB disease. Unfortunately, race specific resistant can promote the buildup of new Xoo race and result in the failure of resistant rice varieties. On the other hand, chemical pesticides which applied

Corresponding Author: Yulin Lestari, Department of Biology, Faculty of Mathematics and Natural Sciences,

Bogor Agricultural University, Darmaga Campus, Bogor 16680, Indonesia Tel/Fax: +62-251-8622833 
preventively and creatively can be an effective method to control BLB, but it is toxic to users, consumers and other non-target organism and may persistent in nature thus accumulate in ecosystems. This condition may have a negative impact on the environment in the long term. Application with bactericides such as Kasugamycin, Phenazin and Streptomycin can suppress the intensity of the BLB in the field but farmers will still have an obstacle because the price is expensive and not environmentally friendly. Alternative control methods can be developed for effectively controlling BLB in rice plant.

One component of integrated disease control is biological control using microorganisms from Actinomycetes group. Actinomycetes are a group of filamentous, Gram positive bacteria with a high $\mathrm{G}+\mathrm{C}$ content in their DNA. These organisms are aerobic, saprophytic and mesophilic forms whose natural habitat in soil. Several members of the Actinomycetes produce important secondary metabolites, including antibiotics, siderophore, enzyme and plant growth-promoting substances which may contribute to their host plants by promoting growth and enhancing their ability of withstanding the environmental stressing (Khamna et al., 2009; Qin et al., 2011). Over 55\% of antibiotics have been isolated from genus Streptomyces (Embley and Stackebrandt, 1994) and therefore this genus is one of several biological control agents which are widely studied and used to control various plant pathogens (ElAbyad et al., 1993). For instance, Prabavathy et al. (2006) reported that the effectiveness of Streptomyces sp. PM5 inhibit the mycelia growth of rice blast fungus Pryricularia oryzae and the rice sheath blight fungus Rhizoctonia solani was related to the production of aliphatic antifungal compounds (SPM5C-1 and SPM5C-2) which have lactone and ketone carbonyl units. Commercial formulation of antibiotics or mycelia and spores of Streptomyces that are effective to control Rhizoctonia solani on rice and Fusarium wilt and Botrytis gray mold on vegetable crops or ornamental plants have been sold under the name Jinggangmycin and Mycostop ${ }^{\mathrm{TM}}$ in Finland (Fravel, 2005).

Indigenous Streptomyces spp. isolated from Indonesia soil were reported to produce a variety of compounds which inhibiting the growth of Grampositive bacteria Bacillus subtilis and Gram-negative Xanthomonas axonopodis (Lestari, 2006). Five Streptomyces isolates that inhibited Xoo growth in agar medium tests were shown to effectively suppress Xoo infection under pot experiment using sterile soil (Unpublished data). However, effective control by Streptomyces under controlled environment conditions may not be transferable to the field conditions. Complex interaction present in natural soil among indigenous soil microorganisms, host, pathogen and a variety of environmental conditions, which can positively or negatively affect the biological control activity of microbes. This suggests that the effectiveness of Streptomyces spp. to control BLB disease must be assessed further in the field. To our knowledge, field efficacy of Streptomyces to control Xoo infection and its simultaneous effects on plant growth and yield has not been well studied in Indonesia. The purposes of this study were to (1) evaluate the ability of Streptomyces spp. to control natural Xoo infections in the field and (2) study the effect of Streptomyces spp. on the rice plant growth and yield.

\section{MATERIALS AND METHODS}

The experiment was conducted in two cropping seasons, dry season (May until September, 2009) and wet season (December 2009 until April 2010) at the Muara Experimental Research Station, Bogor, West Java, Indonesia and Laboratory of Soil Biology, Indonesian Soil Research Institute. A composite soil sample of Latosol surface layer (0-20 cm depth) was collected and analyzed for soil $\mathrm{pH}, \mathrm{C}$-organic and selected nutrients according to standard procedures of the Soil Chemistry Laboratory of Indonesian Soil Research Institute (ISRI) in Bogor. Data in Table 1 indicates that the soil is acidic, with low organic content, low Cation Exchange Capacity and $\mathrm{P}$ content is very high. Population of soil microbes as prior to planting was $6.4 \times 10^{5} \mathrm{cfu}$, actinomycetes $4.6 \times 10^{5} \mathrm{cfu}$ and fungi $2.3 \times 10^{3} \mathrm{cfu}$ per gram of soil. Three isolates (PS4-16, LBR-02 and LSW-05) obtained from Microbiology Division, Department of Biology, Faculty of Mathematics and Natural Sciences, Bogor Agricultural University were used in these experiments.

Streptomyces spp. Preparation: Each Streptomyces spp. Isolate was propagated in $200 \mathrm{ml}$ of ISP- 4 medium and incubated for 10 days at room temperature. The culture was harvested by centrifuging at 10,000 rpm (Beckman Coultier, Avanti ${ }^{\circledR} \mathrm{J}$-E) for 15 minutes to separate the pellet from the supernatant. For preparation of peat-based formula, $2 \mathrm{~g}$ of cell biomass was mixed with $40 \mathrm{~g}$ sterile peat and incubated for a week. To prepare a liquid formulation, the pellet and supernatant were mixed in a ratio of $1: 1$ and $40 \mathrm{~mL}$ of this mixture was diluted in $4 \mathrm{~L}$ of water containing $1 \%$ gum Arabic and 5 drops of Tween 20.

Planting preparation: Two hundred grams of rice seed (cv. IR 64, susceptible to Xoo race IV) was rinsed with tap water and soaked for 24 hours to stimulate germination. 
Am. J. Agri. \& Biol. Sci., 7 (2): 217-223, 2012

Table 1: Soil chemical characteristic in Muara Experimental Research Station, Bogor, West Java Province, Indonesia

Soil characteristic

$\mathrm{pH}$ (extract 1:5)

$\mathrm{H}_{2} \mathrm{O}$

$\mathrm{KCl}$

Organic content

$\begin{array}{lr}\% \text { C (Walkley\& Black) } & 1.71 \\ \% \text { N (Kjeldahl) } & 0.15\end{array}$

$\begin{array}{lr}\% \mathrm{~N} \text { (Kjeldahl) } & 0.15 \\ \mathrm{C} / \mathrm{N} & 11.00\end{array}$

$\mathrm{HCl} 25 \%$

$\mathrm{P}_{2} \mathrm{O}_{5}(\mathrm{mg} / 100 \mathrm{~g})$

$\mathrm{K}_{2} \mathrm{O}(\mathrm{mg} / 100 \mathrm{~g})$

$\mathrm{P}_{2} \mathrm{O}_{5}(\mathrm{ppm})$ Olsen

$\mathrm{K}_{2} \mathrm{O}(\mathrm{ppm})$ Morgan

CEC $\left(\mathrm{NH}_{4}\right.$-Acetat $\left.1 \mathrm{~N}, \mathrm{pH} 7\right)$

$\mathrm{Ca}(\mathrm{cmol}(+) / \mathrm{kg})$

$\mathrm{Mg}(\mathrm{cmol}(+) / \mathrm{kg})$

$\mathrm{K}(\mathrm{cmol}(+) / \mathrm{kg})$

$\mathrm{Na}(\mathrm{cmol}(+) / \mathrm{kg})$

Total

CEC (\%)

BS $(\%)$

$\mathrm{Al}^{3+}(\mathrm{cmol} / \mathrm{kg})$

$\mathrm{H}^{+}(\mathrm{cmol} / \mathrm{kg})$

CEC $=$ Cation Exchange Capacity, BS = Base Saturation

147.00

19.00

176.00

113.00

10.32

2.93

0.22

0.19

13.66

16.32

84.00

0.01

0.11

Half of the soaked seeds were coated with the Streptomyces inoculants at a dose of 200 grams ha $^{-1}$ and amended with Gum Arabic 2\% as an adhesive. Both coated and uncoated seeds were planted in separate seedbeds. After 21 days in the nursery, seedlings were uprooted. Seedlings grown from uncoated seeds were directly transplanted to experimental plots, whereas the pre-coated seedlings were soaked for $15 \mathrm{~m}$ in liquid formulation of Streptomyces prior to planting.

Field experiment set up: All trials used plot sizes of $5 \times 5 \mathrm{~m}^{2}$ and planting distances of $20 \times 20 \mathrm{~cm}^{2}$ with one seedling per planting hole. Basic fertilizer $(200 \mathrm{~kg}$ of urea, $100 \mathrm{~kg}$ of SP36 and $100 \mathrm{~kg}$ of $\mathrm{KCl} \mathrm{ha}^{-1}$ ) was provided in accordance with the results of soil analysis before planting or dosage recommendations in the study site.

Dry season experiment: Two isolates of Streptomyces spp. (LBR-02 and PS4-16) were applied in three ways: A: seed coating followed by soaking seedlings, B: spraying and $\mathrm{C}$ : combination of method $\mathrm{A}$ and $\mathrm{B}$. Treatments were consisted of six Streptomyces combination of isolating and application method which were compared to the standard chemically-sprayed plots with NORDOX $56 \mathrm{WP}$ and non-treated plots as follows:

- $\quad$ Method A + LBR-02

- Method A + PS4-16

- Method B + LBR-02

- Method B + PS4-16
- $\quad$ Method C + LBR-02

- Method C + PS4- 16

- Spray application of NORDOX 56WP (2.0-2.5 g $\mathrm{L}^{-1}$ of water) and

- Non- treated plots

Spraying application of Streptomyces was conducted every two weeks, started at 8 days after planting until 63 DAP. For comparison of Streptomyces inoculants treatment, the plant sprayed with NORDOX 56 WP which was widely used by farmers in the northern coastal strip of West Java to control the BLB disease. NORDOX 56 WP was sprayed with frequency and time interval equal to the spraying of Streptomyces.

Wet season experiment: One additional isolate (LSW05) was included in this trial. Streptomyces was applied using only method A, either singly or in combination with the other isolates. Method A was chosen because it was shown to be the most effective application method (see Results). Six Streptomyces treatment combinations were tested and compared to the standard chemically-sprayed and non-treated plots as follows:

- Method A + LBR-02

- Method A + PS4-16

- Method A + LSW-05

- Method A + LBR-02 + PS4-16

- Method A + LBR-02 + LSW-05

- Method A + LBR-02 + PS4-16 + LSW-05

- Spray application of NORDOX 56WP (2.0-2.5 g $\mathrm{L}^{-1}$ of water) and

- Non- treated plots

Disease evaluation: Efficacy of Streptomyces was evaluated based on the percentage of infected plants and disease severity. The percentage of infected plants were calculated based on the proportion of infected plants per plot. Ten randomly selected plants from each plot were scored for disease severity using the Standard Evaluation System of IRRI (IRRI, 1996) was: $0=$ no symptoms, $1=1-5 \%$ infected leaves, $3=6-12 \%, 5=$ $13-25 \%, 7=26-50 \%$ and $9=51-100 \%$ infected leaves. The disease scores were used to calculate the score of Disease Severity of Index (DSI) using the formula:

DSI $=\left\{\left(a_{1} \mathrm{~N}_{1}+a_{2} \mathrm{~N}_{2}+\ldots+a_{n} \mathrm{~N}_{n}\right) /(\right.$ number of plants scored $\times 9)\} \times 100$

where, a is the score of each plant and $\mathrm{N}$ was the number of plants with a certain score. The DSI data from all observation dates was converted to the Area 
Am. J. Agri. \& Biol. Sci., 7 (2): 217-223, 2012

under Disease Progress Curve (AUDPC) using the following formula:

$$
\operatorname{AUDPC}=\sum_{\mathrm{i}=\mathrm{n}}^{\mathrm{n}}\left\{\left(\left[\mathrm{R}_{\mathrm{i}+1}+\mathrm{R}_{\mathrm{i}}\right] / 2\right) \times\left(\mathrm{t}_{\mathrm{i}+1}-\mathrm{t}_{\mathrm{i}}\right)\right\}
$$

Here, $R_{i}$ is DSI on the $i$-th observation, $t$ is time of observation and $n$ is the number of observations. In the dry season experiment, disease evaluation was done biweekly starting at 14 until 70 DAP, whereas in the wet season experiment, it was done once a week starting 43 until 77 DAP.

Agronomic evaluation: The 10-plant samples scored for disease severity was also observed for plant height, number of tillers, plant biomass and weight of filling the grain. Plant yield parameters which included the weight of dry grain and dry milled grain were obtained per plot. Plant height was measured weekly from 29-56 DAP in dry season and at 20,32 and 70 DAP in the wet season. Plant height data from all evaluation dates was converted to the Area Under plant Height Progress Curve (AUHPC) using the formula analog to AUDPC calculation as described previously. The numbers of tillers were observed once weeks starting from 35 until 56 DAP in dry season trial and once at 77 DAP in the wet season trial. Plants were harvested at 95 DAP (dry season) and at 105 DAP (wet season).

Statistical analysis: Both experiments were carried out in a randomized block design with four replications for each treatment. Data were analyzed using the General Linear Model procedure of SPSS 12.0. Mean separation between treatments was done using the Duncan Multiple Range Test (DMRT) at $\mathrm{p}=0.05$.

\section{RESULTS}

Dry season experiment: Xoo infection occurred at 14 DAP and increased with increasing age of the plant. Evaluation on the percentage of infected plants were done four times and terminated at 56 DAP when more than $93 \%$ plants have been infected in all experimental plots. At all evaluation dates, application of Streptomyces or NORDOX 56 WP did not significantly affect the percentage of infected plants $(p>0.05)$, but significantly affected the AUDPC values at 70 DAP ( $<<0.05$; Table 2). In general, PS4-16 was superior compared to LBR-02 in suppressing BLB disease, especially when applied using Method A (the seed coating followed by seedling soaking). The disease suppression by PS4-16 applied using this method was equally effective (AUDPC value 1458) to the spray application of NORDOX 56 WP (AUDPC value 1434).
Table 2: Effect of Streptomyces application on bacterial leaf blight on a CV. IR64 in dry season experiment

\begin{tabular}{lll}
\hline Treatment $^{*}$ & $\begin{array}{l}\text { Infected plants } \\
\text { on 56 DAP }(\%)^{* *}\end{array}$ & $\begin{array}{l}\text { AUDPC values } \\
\text { at 70 DAP }\end{array}$ \\
\hline $\begin{array}{l}\text { Method and Isolate } \\
\text { A + LBR-02 }\end{array}$ & 96.3 & $1694 \mathrm{c}$ \\
A + PS4-16 & 94.0 & $1458 \mathrm{a}$ \\
B + LBR-02 & 94.5 & $1606 \mathrm{abc}$ \\
B + PS4-16 & 96.4 & $1661 \mathrm{bc}$ \\
C + LBR-02 & 94.2 & $1602 \mathrm{abc}$ \\
C + PS4-16 & 94.3 & $1480 \mathrm{ab}$ \\
Spray application & 93.3 & $1434 \mathrm{a}$ \\
of NORDOX 56WP & & \\
No treatment & 95.1 & $1711 \mathrm{c}$ \\
\hline
\end{tabular}

The number on the lines indicated by the same letter in same column indicates no significant difference at the 5\% level of DMRT. *: Method A: seed coating followed by soaking seedlings soaking, Method B: spraying and Method C: combination of method A and B. ${ }^{* *}$ : DAP = day after planting, averages from 4 replicated plots of $5 \times 5 \mathrm{~m}^{2}$ size. $^{* * *}$ : AUDPC area under disease progress curve. Average of 10 plants $\times 4$ replications

Table 3: Effect of Streptomyces application on plant growth of rice CV. IR 64 in dry season experiment

\begin{tabular}{clll}
\hline & $\begin{array}{l}\text { AUHPC } \\
\text { Values in } \\
\text { 56 DAP }\end{array}$ & $\begin{array}{l}\text { Number } \\
\text { of tillers }\end{array}$ & $\begin{array}{l}\text { Weight of plant } \\
\text { biomass (kg) }\end{array}$ \\
\hline $\begin{array}{c}\text { Method and Isolate } \\
\text { A + LBR-02 }\end{array}$ & $\begin{array}{l}\text { 2475abc } \\
\text { 2639a }\end{array}$ & 17.2 & 0.6 \\
A + PS4-16 & 16.4 & 0.6 \\
B + LBR-02 & $2512 \mathrm{abc}$ & 16.4 & 0.6 \\
B + PS4-16 & $2382 \mathrm{c}$ & 16.1 & 0.6 \\
C + LBR-02 & $2447 \mathrm{bc}$ & 16.4 & 0.6 \\
C + PS4-16 & 2574ab & 16.3 & 0.7 \\
$\begin{array}{l}\text { Spray application } \\
\text { of NORDOX 56WP }\end{array}$ & $2357 \mathrm{c}$ & 17.8 & 0.7 \\
No treatment & $2443 \mathrm{bc}$ & 16.3 & 0.7 \\
\hline
\end{tabular}

The number on the lines indicated by the same letter in same column indicates no significant difference at the $5 \%$ level of DMRT. ${ }^{*}$ Method A: seed coating followed by seedlings soaking, Method B: spraying and Method C: combination of method A and B. ${ }^{* *}$ AUHPC area under plant high progress curve. Average from 10 plants $x 4$ replications

Table 4: Effect of Streptomyces application on rice yield of CV. IR64 in the dry season experiment

\begin{tabular}{llll}
\hline Treatment $^{*}$ & $\begin{array}{l}\text { Dry grain yield } \\
\text { per plot }(\mathrm{kg})^{* *}\end{array}$ & $\begin{array}{l}\text { Dry milled grain } \\
\text { per plot }(\mathrm{kg})\end{array}$ & $\begin{array}{l}\text { Filled grain } \\
(\mathrm{g})^{* * *}\end{array}$ \\
\hline Method and isolate & & & \\
A+ LBR-02 & $10.4 \mathrm{abc}$ & $9.2 \mathrm{bc}$ & $8.1 \mathrm{ab}$ \\
$\mathrm{A}+$ PS4-16 & $12.0 \mathrm{a}$ & $10.6 \mathrm{a}$ & $9.3 \mathrm{a}$ \\
$\mathrm{B}+$ LBR-02 & $10.0 \mathrm{bc}$ & $8.9 \mathrm{bc}$ & $7.9 \mathrm{~b}$ \\
B + PS4-16 & $9.3 \mathrm{c}$ & $8.1 \mathrm{c}$ & $7.4 \mathrm{~b}$ \\
C + LBR-02 & $11.0 \mathrm{ab}$ & $9.5 \mathrm{ab}$ & $8.4 \mathrm{ab}$ \\
C + PS4-16 & $11.0 \mathrm{ab}$ & $9.7 \mathrm{ab}$ & $8.5 \mathrm{ab}$ \\
Spray application & $9.9 \mathrm{bc}$ & $8.8 \mathrm{bc}$ & $7.8 \mathrm{~b}$ \\
of NORDOX 56WP & & & \\
No treatment & $9.8 \mathrm{bc}$ & $8.9 \mathrm{bc}$ & $7.8 \mathrm{~b}$ \\
\hline
\end{tabular}

The number on the lines indicated by the same letter in same column indicates no significant difference at the 5\% level of DMRT. *: Method A: seed coating followed by seedling soaking, Method B: spraying and Method C: combination of method A and B. ${ }^{* *}$ : averages from 4 replicated plots of $5 \times 5 \mathrm{~m}^{2}$ size. ${ }^{* * *}$ Average of 10 plants $\times 4$ replications

All treatment significantly influenced the AUPHC values at 56 DAP $(p<0.05)$ but did not affect plant tiller number and biomass (Table 3 ). 
Table 5: Effect of single or combined application of Streptomyces isolates on bacterial leaf blight severity caused by Xanthomonas oryzae pv. oryzae on cv IR64 in wet season experiment

\begin{tabular}{lll}
\hline Treatment $^{*}$ & $\begin{array}{l}\text { Infected plants } \\
\text { at 70 DAP (\%) }\end{array}$ & $\begin{array}{l}\text { AUDPC values } \\
\text { at 70 DAP*** }\end{array}$ \\
\hline Method A and Isolate & 90.2 & $2012 \mathrm{ab}$ \\
LBR-02 & 91.0 & $1923 \mathrm{a}$ \\
PS4-16 & 92.3 & $2180 \mathrm{~b}$ \\
LSW-05 & 90.7 & $2092 \mathrm{ab}$ \\
LBR-02 +PS4-16 & 87.6 & $2186 \mathrm{~b}$ \\
LBR-02 +LSW-05 & 90.0 & $2152 \mathrm{~b}$ \\
LBR-02 + PS4-16+LSW-05 & 90.9 & $1934 \mathrm{a}$ \\
Spray application & & $2097 \mathrm{ab}$ \\
of NORDOX 56WP & 90.6 & \\
No treatment &
\end{tabular}

The number on the lines indicated by the same letter in same column indicates no significant difference at the 5\% level of DMRT *: Method A: seed coating followed by seedling soakings ***Average from 10 plants $\times 4$ replications

Table 6: Effect of single or combined application of Streptomyces isolates on plant growth of rice cv. IR64 in wet season experiment

\begin{tabular}{llll}
\hline $\begin{array}{l}\text { plant } \\
\text { Treatment }\end{array}$ & $\begin{array}{l}\text { AUHPC values } \\
\text { Method A and Isolate }\end{array}$ & $\begin{array}{l}\text { Number of Weight of the } \\
\text { at 71 DAP** }\end{array}$ & $\begin{array}{l}\text { tiller** } \\
\text { biomass }(\mathrm{kg})^{* *}\end{array}$ \\
LBR-02 & $3867 \mathrm{a}$ & $15.5 \mathrm{ab}$ & $0.71 \mathrm{ab}$ \\
PS4-16 & $3744 \mathrm{ab}$ & $3.7 \mathrm{c}$ & $0.73 \mathrm{a}$ \\
LSW-05 & $3592 \mathrm{bc}$ & $14.0 \mathrm{bc}$ & $0.61 \mathrm{bc}$ \\
LBR-02 +PS4-16 & $3722 \mathrm{ab}$ & $15.0 \mathrm{abc}$ & $0.66 \mathrm{abc}$ \\
LBR-02 +LSW-05 & $3757 \mathrm{ab}$ & $16.0 \mathrm{a}$ & $0.70 \mathrm{ab}$ \\
LBR-02 + PS4-16+LSW-05 & $3775 \mathrm{ab}$ & $15.6 \mathrm{a}$ & $0.72 \mathrm{a}$ \\
Spray application & $3538 \mathrm{c}$ & $15.5 \mathrm{ab}$ & $0.57 \mathrm{c}$ \\
of NORDOX 56WP & & & \\
No treatment & $3517 \mathrm{c}$ & $15.1 \mathrm{abc}$ & $0.64 \mathrm{abc}$ \\
\hline
\end{tabular}

The number on the lines indicated by the same letter in same column indicates no significant difference at the $5 \%$ level of DMRT * Method A: seed coating followed by seedling soaking

${ }^{* *}$ Average from 10 plants $\times 4$ replications

Table 7: Effect of single or combined application of Streptomyces isolates on yield of rice cv. IR64 in wet season experiment

\begin{tabular}{llll}
\hline Treatment $^{*}$ & $\begin{array}{l}\text { Dry grain } \\
\text { weight }(\mathrm{kg})\end{array}$ & $\begin{array}{l}\text { Dry milled } \\
\text { grain }(\mathrm{kg})\end{array}$ & $\begin{array}{l}\text { Filled } \\
\text { grain }(\mathrm{g})\end{array}$ \\
\hline Method A and Isolate & & & \\
LBR-02 & 8.2 & 7.3 & 6.6 \\
PS4-16 & 8.5 & 7.5 & 6.5 \\
LSW-05 & 7.6 & 6.9 & 6.0 \\
LBR-02 +PS4-16 & 8.0 & 6.7 & 6.1 \\
LBR-02 +LSW-05 & 8.4 & 7.5 & 6.8 \\
LBR-02 + PS4-16+LSW-05 & 8.7 & 7.8 & 7.1 \\
Spray application & 7.6 & 6.8 & 6.1 \\
of NORDOX 56WP & & & \\
No treatment & 8.0 & 7.2 & 6.4 \\
\hline
\end{tabular}

The number on the lines indicated by the same letter in same column indicates no significant Difference at the 5\% level of DMRT* Method A: seed coating followed by seedling soaking

With exception of the application of PS4-16 using Method B and LBR-02 using Method C, disease suppression by all Streptomyces applications resulted in increased plant height. In contrast, plants received NORDOX 56 WP treatment did not show improved plant height despite low levels of BLB severity. PS4-16 in general was also superior to LBR-02 in increasing plant height, especially when applied using Method A.

Plant yield, as measured by the weight of dry grain yield, dry milled grains and filled grains, were significantly affected by all treatments $(p<0.05)$. The highest yield was obtained from application of PS4-16 using Method A (Table 4).

Wet season experiment: BLB disease developed slowly at the onset of the trial. Percentages of infected plants as high as $87 \%$ was achieved at 70 DAP. All treatments did not significantly affect the proportion of infected plants $(p>0.05)$, but affected AUDPC values at 77 DAP $(p<0.05$ : Table 5). PS4-16 applied singly was the most effective treatment in suppressing BLB severity with AUDPC value of 1923, which was comparable to that of spray application with NORDOX 56 WP (AUDPC value 1934). LBR-02 applied singly or in combination with PS4-16 was also fairly effective to reduce the disease, with the AUDPC values of 2012 and 2092, respectively. LSW-05 had the lowest effectiveness compared to other isolates. Dual or triple combination of LSW-05 with the other isolates did not always improve its effectiveness (Table 5).

Plant growth as measured by AUHPC values, number of tillers and plant biomass, was significantly affected by all treatment applications $(p<0.05)$. Plants received Streptomyces treatment not always show significant difference of plant growth compared to the NORDOX 56 WP and non-treated plots (Table 6). Single or combined Streptomyces isolates were equally effective in promoting plant growth except for PS4-16, which did not increase the number of tillers and LSW05, which did not promote the three growth parameters.

In contrast to the dry season experiment results, Streptomyces application in the wet season trial had no significant effect on rice yield as measured by the weight of dry grain, dry milled grain and filled grain (Table 7). However, PS4-16 and LBR-02, either given singly or in dual or triple combination with the other isolates, tended to increase rice yield compared to that of NORDOX 56 WP or non-treated plants.

\section{DISCUSSION}

In this study, BLB disease control was successfully achieved by the application of Streptomyces through seed coating, followed by seedlings soaking during two planting seasons (wet season and the dry season). A single application of Streptomyces PS4-16 inoculant was effective in controlling BLB disease with the value of AUDPC 1923 and 1458 in the wet season and dry season 
respectively. The disease suppression by PS4-16 was equal to that obtained from the chemical spray with NORDOX 56 WP. LBR-02 was less effective than PS4-16, whereas LSW-05 was least effective compared to both isolates. These results partly confirmed the results of in vitro studies by Papuangan (unpublished data) in which the isolates used in this study were able to inhibit the growth of Xanthomonas oryzae pv. oryzae (Xoo) to form a clear zone of $4 \mathrm{~mm}$ (PS4-16) and $5.5 \mathrm{~mm}$ (LBR-02). Furthermore, the result also confirmed the effectiveness in a greenhouse experiment by using sterile soil (Hastuti, unpublished data) which showed that these isolates could suppress the BLB disease in IR64 Rice plants. This shows that under natural conditions many factors may inversely affect the effectiveness of Streptomyces and therefore field studies are needed.

The ability of rhizosfer bacteria such as Streptomyces, when applied as a seed dressing, to reduce foliage pathogen infection was also documented by other workers. Sabaratnam and Traquiaria (2002); Shimizu et al. (2009) and Patil et al. (2010) reported that seed application of Streptomyces successfully control damping off by Rhizoctonia solani in tomato seed with maximum disease suppression $53.33 \%$ and cucumber anthracnose on cucumber (Cucumis sativus L.,) caused by Colletotrichum orbiculare.

As biological control agents, Streptomyces could indirectly act through increased plant fitness whereas the disease suppression may occur through the induction of systemic resistance of plants and production of bioactive compounds, such as antibiotic compounds, siderophore and some lytic enzymes such as glucanase, chitinase and cellulase (Compant et al., 2005; Hasegawa et al., 2006). It could be seen from Table 3, where the inoculation of Streptomyces can suppress the severity of the disease has a positive effect on plant height, while giving NORDOX 56WP only able to suppress the severity of the disease course. Streptomyces can inhibit Xoo through antagonistic mechanism and it, also capable of producing growth regulators or Indole Acetic Acid (IAA). Another mechanism by which disease suppression occurs in foliage by rhizosfer bacteria is induced systemic resistance or ISR (Choudhary et al., 2007). Plant resistance mechanism in this way involves the translocation of plant signal from roots to foliage that activates plant resistance. Application of Streptomyces through seed coating may induce systemic resistance. Early colonizing roots of germinated seeds may activate natural plant resistance mechanisms that will increase the capacity of plant defenses against multiple pathogens that will attack later. Soaking seeds in Streptomyces suspension further increase the population of Streptomyces that can colonize the roots.
Although Streptomyces seems to be very promising as Xoo biocontrol agents from our point of view, their development into commercial formulation poses several difficulties. The carrier material used must provide favorable conditions for long shelf-life and survival in soil when applied (Georgakopoulos et al., 2002). Addition of selective substrates such as calcium-alginate was reported by Shrivastava et al. (2008) to increase the effectiveness of Streptomyces. Many factors can determine the viability and effectiveness of biological control agents by Streptomyces, among others; environmental conditions such as soil temperature, soil water status, soil nutrient availability and population density of pathogens (Xiao et al., 2002) can certainly influence the biological function of microbial inoculants. Therefore, further studies are needed to develop a better formulation for long-term storage with an effective population density of Streptomyces and asses its field efficacy in multi-location trials.

\section{CONCLUSION}

Streptomyces spp. Generally suppressed BLB disease severity although it did not reduce the percentage of infected plants. Streptomyces PS4-16 which was applied through seed coating and seedling soaking techniques was consistently the most effective Streptomyces isolate in controlling BLB disease during dry and wet season trials. An AUDPC value obtained from this treatment was 1458 and 1923, for dry and wet season respectively, which are comparable to those obtained from the standard chemical spray. Streptomyces isolates, especially PS4-16 tended to increase plant growth and yield.

\section{ACKNOWLEDGEMENT}

This study was partly supported by a research grant from the Collaborative Research Project of KKP3T between the Agency for Agricultural Research and Development (AARD), Indonesian Ministry of Agriculture and Bogor Agricultural University (IPB) and partly supported by a Graduated Research Grant from the Directorate General of Higher Education of Republic of Indonesia awarded to Dr. Yulin Lestari.

\section{REFERENCES}

Choudhary, D.K., A. Prakash and B.N. Johri, 2007. Induced Systemic Resistance (ISR) in plants: Mechanism of action. Indian. J. Microbiol., 47: 289-297. DOI: 10.1007/s12088-007-0054-2 
Compant, S., B. Duffy, J. Nowak, C. Clement and E.A. Barka, 2005. Use of plant growth-promoting bacteria for biocontrol of plant diseases: Principles, mechanisms of action and future prospects. Applied Environ. Microbiol., 71: 4951-4959.

El-Abyad, M.S., M.A. El-Sayed, A.R. El-Shansburry and S.M. El-Sabbagh, 1993. Towards the biological control of fungal and bacterial diseases of tomato using antagonistic Streptomyces spp. Plant Soil., 149: 185-195. DOI: 10.1007/BF00016608

Embley, T.M. and E. Stackebrandt, 1994. The molecular phylogeny and systematics of the actinomycetes. Ann. Rev. Microbiol., 48: 257-289. PMID: 7529976

Fravel, D.R., 2005. Commercialization and implementation of biocontrol. Ann. Rev. Phytopathol., 43: 337-359. DOI: 10.1146/annurev.Phyto.43.032904.092924

Georgakopoulos, D.G., P. Fiddaman, C. Leifert and N.E. Malathrakis, 2002. Biological control of cucumber and sugar beet damping-off caused by Pythium ultimum with bacterial and fungal antagonists. J. Applied Microbiol., 92: 1078-1086. DOI: 10.1046/j.1365-2672.2002.01658.x

Hasegawa, S., A. Meguro, M. Shimizu, T. Nishimura and H. Kunoh, 2006. Endophytic actinomycetes and their interactions with host plants. Actinomycetologica, 20: 72-81. DOI: 10.3209/saj.20.72

IRRI, 1996. 1988. Standard Evaluation System for Rice. 4th Edn., International Rice Research Institute, Manila, Philippines, pp: 52.

Khamna, S., A. Yokota and S. Lumyong, 2009. Actinomycetes isolated from medicinal plant rhizosphere soils: Diversity and screening of antifungal compounds, indole-3-acetic acid and siderophore production. World J. Microbiol. Biotechnol., 25: 649-655. DOI: 10.1007/s11274008-9933-x
Lestari, Y., 2006. Short communication : Identification of indigenous Streptomyces spp. Producing antibacterial compounds. J. Mikrobiol. Indones, 11: 99-101.

Patil, H.J., A.K. Srivastava, S. Kumar, B.L. Chaudari and D.K. Arora, 2010. Selective isolation, evaluation and characterization of antagonistic actinomycetes against Rhizoctonia solani. World J. Microbiol. Biotechnol., 26: 2163-2170. DOI: 10.1007/s11274-010-0400-0

Prabavathy, V.R., N. Mathivanan and K. Murugesan, 2006. Control of blast and sheath blight diseases of rice using antifungal metabolites produced by Streptomyces sp. PM5. Biol. Control, 39: 313-319. DOI: 10.1016/j.biocontrol.2006.07.011

Qin, S., K. Xing, J.H. Jiang, L.H. Xu and W.J. Li, 2011. Biodiversity, bioactive natural products and biotechnological potential of plant-associated endophytic actinobacteria. Applied Microbiol. Biotechnol., 89: 457-473. DOI: 10.1007/s00253010-2923-6

Sabaratnam, S. and J.A. Traquaira, 2002. Formulation of a Streptomyces biocontrol agent for the suppression of Rhizoctonia damping-off in tomato transplants. Biol. Control, 23: 245-253. DOI: 10.1006/bcon.2001.1014

Shimizu, M., S. Yazawa and Y. Ushijima, 2009. A promising strain of endophytic Streptomyces $\mathrm{Sp}$. For biological control of cucumber anthracnose. J. Gen. Plant. Pathol., 75: 27-36. DOI: 10.1007/s10327-008-0138-9

Shrivastava, S., S.F. D'Souza and P.D. Desai, 2008. Production of indole-3-acetic acid by immobilized actinomycete (Kitasatospora sp.) for soil applications. Curr. Sci., 94: 1595-1604.

Xiao, K., L.L. Kinkel and D.A. Samac, 2002. Biological control of Phytophthora root rots on alfalfa and soybean with Streptomyces. Biol. Control, 23: 285-295. DOI: 10.1006/bcon.2001.1015 